\title{
University of New South Wales
}

\author{
Stephen Muecke
}

\section{A diplomat for the history wars}

\begin{abstract}
:
In this experimental reflection on the 'history wars' associated with Keith Windschuttle's writings, the author recruits a storyteller, an ex-diplomat, whose yarning style subtly contests the 'graphocentrism' of Windschuttle's faith in the truth of the written document. For the latter, facts are both enshrined in print, yet forever 'out there' in the world innocently waiting to be gathered. Against this, the essay argues that facts are indeed 'fabricated' - in an appropriation of Windschuttle's critique of black

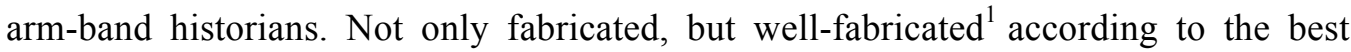
protocols and methods of historical research. If historical facts are thus constructed, they must also be institutionally supported so that they can continue to exist, and that too is an on-going negotiation in which diplomacy must also play a part. The negotiation is not between the veracity of facts and the distortions of ideology; peace will never be achieved along that pathway. The real war is between the most cherished values that support the manufacture of the facts that serve the parties involved. The skilled diplomat intervenes to listen to what it is they hold most dear, and then negotiates what they might relinquish to achieve a workable peace.
\end{abstract}

\section{Biographical note:}

Stephen Muecke is Professor of Ethnography at the University of New South Wales, Sydney, where he is part of the Environmental Humanities programme. He has written extensively on Indigenous Australia, especially in the Kimberley, and on the Indian Ocean. Recent books are Butcher Joe, Documenta 13, Hatje Cantz Verlag, Ostfildern, 2011 and Contingency in Madagascar, with photographer Max Pam, in Intellect Books' Critical Photography Series, 2012.

Keywords:

Storytelling - Diplomacy - History wars - Fictocritical writing - Experimental history 
Sydney, Tuesday, October 15, 2013: A right-wing government has just been elected in Canberra, and the new Education Minister, Christopher Pyne, has already made statements reported as having the potential to reignite the 'history wars' of the Howard era. ${ }^{2}$

Concerned about this tendency in the government and the media to want to go straight to war without even thinking of having a reasoned debate or taking steps to reconcile opposing views, the writer, Stephen Muecke, has sought the wisdom of a friend of the family, a former diplomat, in Afternoon Light, an old folks' home in the northern suburb of Pymble in Sydney.

The old man is the veteran of some very real 'theatres of war' - he was at the fall of Singapore - but has also thought about the events of the past in terms of the need for 'cultural diplomacy'. I arrive with my voice recorder, and I am mildly surprised to find a few of the old man's friends sitting around in the garden with him. They are there to enjoy the exchange, which is transcribed here verbatim: ${ }^{3}$

I've got a few of the other 'inmates' here with me [laughs]-

Is that $\mathrm{OK}$ ? - - -

You want a cuppa, young fella?

SM: No, that's fine, and yes, yes please ---

[recorder starts again]

Well ----

I can tell you this story --

if you like? -

Oh, not a long story, only a short one ---

it's about that fight over history ---

in the late nineties -

about the time of the Howard government -

well during the time of the Howard government anyway - - -

Everybody knows this story -

And everybody knows about history

or at least they think they do ---

history comes in books - 
that much is pretty clear-

writing is what organizes history ---

But if you tell stories -

Well, that's just talk, idle chatter -

but we know all about what they call oral history too -

when the spoken word can count as true -

in some ways -

But anyway, that's just the frame for my story -

but I'll come back to it - -

now I want to paint the picture ---

So, there was this guy -

living in Sydney

Windschuttle I think they called him

[listener: Keith Windschuttle]-

That's right, thanks, his name was Keith Windschuttle -

so he wrote this book that made a really big stink and

everyone was talking about it -

all over the newspapers -

The Fabrication of Aboriginal History ---

[listener: he's got four volumes] what's that? [listener again: four books, four volumes]

Really? Four volumes, now --

must be a lot of work, eh? [laughter]

[second listener: only two so far, volumes one and three]

Out of sequence, eh? -- 
oh well, no matter -

he must have a good reason for that --

Anyway, it struck me that with that title The Fabrication of Aboriginal History - he was meaning to say that those he was arguing against -

they got called the 'black armband' version of the historical events of colonization -

then, right after, he and his mates got dubbed the 'white blindfold' mob!

[laughs]--

That the idea of fabrication was that the black armbanders were making things up -

creating politically-correct propaganda -

by carefully selecting the facts to suit the case ---

Well ---

I've seen this before -

when you mediate -

diplomatically -

you know, both sides are inevitably 'making it up', they must have --

they have arrived at that position through a process -

through hard work --

and you don't mediate by saying that somewhere there is a direct path to the truth of the whole matter and try to put them both on the one true path --

as if there is a single truth would resolve the issues -

no --

you try to understand and respect both positions --

understand what each party really holds dear, and why they do --

Then you try to get them to trade:

well, if you can agree with this aspect, then perhaps we can eliminate that difference - 
and so on -

chipping away at their differences --

it's a long slow process --

The diplomat is the mediator -

The cool head between two, or more, passionately held positions -

It's a dangerous situation -

They are itching for a fight these fellas -

Oh I've seen it too -

Those politicians like Howard -

I can say anything now, no-one cares what I think -

Yeah, you can publish anything, young fella, I don't care --

What was I ...? oh, yes, Howard -

Well he was brought up on Churchill -

And Bean and other war histories -

So when he got to be PM, he thought that's what you've got to do! -

To go down in history -

Never underestimate these guys' egos --

War is history -

Or rather history is made by wars - -

True -

To some extent -

But you could also ask, what is it you want to stress in history?

What's your perspective?

My wife was always banging on about the eight-hour day and the suffragettes -

That was history for her -

And didn't take any notice of ANZAC day or anything -

Me neither for that matter; I didn't go on the marches -

Oh, I did once, after we were demobbed -- 
I could tell you what war's really like one day -

That's another story ----

Another story altogether --

But you were wanting to know about diplomacy, eh?

Oh, and Howard -

What I wanted to say about him -

He was brought up adulating Churchill and everything -

So first chance he gets he takes the country into the Iraq war-

Because of a bloody bunch of lies, 'scuse my French -

[Listener: Yes, but that Saddam was a dangerous terrorist, that's what it was about ...]

[Another listener: and oil!]

[everyone starts talking. Recorder stops.

(...)

recorder starts again]

Anyway, despite the differences of opinion about the Iraq war! [laughter] -

War or diplomacy, that's my point -

Politicians, some of them, want to go to war -

Play the hero -

Rather than call in the diplomats -

And newspapers like a good war story -

You remember that famous flick, Citizen Kane?

'You provide the prose poems,' says Kane

- reminds me of Murdoch! - and 'I'll provide the war' --

But not much news, not much drama, to be had in a slow diplomatic process -

So that's why we've seen a decline in the number of diplomats in the foreign service -

Missions reduced through budget cuts - 
As I was saying, the diplomat mediates -

No representation without mediation, as they say ${ }^{4}--$

They go backwards and forwards and each time the brief is revised.

They are in a middle ground ${ }^{5}-$

'diplomatic immunity', waving white flags -

but when they talk -

when they negotiate -

the tone has to be absolutely right --

(a lot of them had literature degrees and no wonder!) --

you can't say the wrong thing - -

but the tone has to be right too -

talking to the others as if you understood their position deeply

and empathized with it -

talking to the others respectfully in their own language -

sometimes literally in their own language, traditionally diplomats were multilingual -

Now, where has that kind of mutual respect gone? -

in the so-called history wars? --

Did Windschuttle ever talk to an Aboriginal person while he was doing his research?

I don't think so -

Certainly doesn't look like it -

No need to talk, he would say -

It's not about memory or oral history -

it's all about documents -

So if there's no need for diplomacy in history, you can go straight to war ---

And diplomacy in actual history gets forgotten too -

Frontier diplomacy -

All those negotiations that took place between whites and blacks - 


\section{From Philip onwards -}

And especially out in the bush, out in that middle ground -

Where people had to negotiate to survive -

There's a history of diplomacy yet to be written there too -

In this country -

But in the history wars 'the facts' get used as a weapon -

There it is, written in a document -

Must be true -

'The facts can speak for themselves' - - -

and you hit your opponent over the head with it! [laughter]

And you thought facts were used for enlightenment [shakes his head slowly] - - -

[end of recording]

\section{Endnotes}

1. Bruno Latour (2004: 460): 'Common experience in science, art, love, and religion should prompt us to say, "the more carefully fabricated, the more real and long-lasting".'

2. See: http://www.smh.com.au/federal-politics/political-news/libs-reignite-culture-wars-overanzac-day-teaching-20130422-2iaro.html.

3. Transcribed by Stephen Muecke according to a method developed for his books with Paddy Roe, a Goolarabooloo elder from Broome, Gularabulu (1983), and Reading the Country (1984). Lines represent breath-groups, and each dash at the end of the line represents a second of pause.

4. 'truth [can] be obtained not by decreasing the number of intermediary steps, but by increasing the number of mediations' (Latour 2010: 601).

5. Which reminds me of Richard White's wonderful 1991 book: The middle ground: Indians, empires, and republics in the Great Lakes Region, 1650-1815

\section{Works cited}

Benterrak, Krim, Stephen Muecke and Paddy Roe 1984 Reading the country: Introduction to nomadology, Fremantle, WA: Fremantle Arts Centre Press

Latour Bruno 2004 'Whose cosmos, which cosmopolitics? Comments on the peace terms of Ulrich Beck' Common Knowledge 10:3 (Fall), 450-62

Latour, Bruno 2010 'Coming out as a philosopher' Social Studies of Science 40:4, 599-608

Muecke Stephen (ed) and Paddy Roe 1983 Gularabulu: Stories from the West Kimberley, Fremantle, WA: Fremantle Arts Centre Press

White, Richard 1991 The middle ground: Indians, empires, and republics in the Great Lakes Region, 1650-1815 Cambridge: Cambridge University Press 